\title{
PENGARUH PRODUK DOMESTIK REGIONAL BRUTO, INVESTASI INDUTRI KECIL DAN JUMLAH PENDUDUK TERHADAP KEMISKINAN KOTA LHOKSEUMAWE (Studi Kasus Tahun 2006-2016)
}

\author{
Umaruddin Usman ${ }^{* a}$, Evi Berutu ${ }^{* b}$ \\ *Fakultas Ekonomi dan Bisnis Universitas Malikussaleh \\ a Corresponding author: umaruddin @unimal.ac.id \\ b eviberutu@gmail.com
}

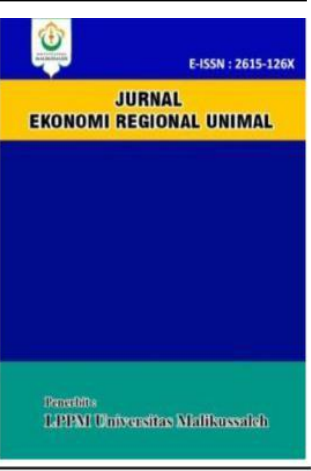

A R T I CLE I N F ORMATION

A B S T R A C T

Keywords:

GRDP, Small Industry

Investment, Population and

Poverty.
The purpose of this study is tosee the effect of GDP, Small-scale Industry Investment, and Population on Poverty in Lhokseumawe City Aceh, Indonesia. This study uses secondary data from the Central Statistics Agency of Lhokseumawe City, in the year 2006-2016. The research method uses multiple regression analysis. The results of the study partially show that GDP has a positive effect on poverty, small industry investment has a negative effect and significance for poverty, and population has no significant effect on poverty, but jointly variable GRDP, Small Industry Investment, and Population positive and significant effect the poverty.

\section{PENDAHULUAN}

Kemiskinan dan pertumbuhan ekonomi merupakan indikator yang penting dalam mencapai keberhasilan pembangunan Negara. Mencapai pembangunan, setiap negara berusaha mengoptimalkan pertumbuhan ekonomi serta mengurangi kemiskinan. Permasalahan yang muncul pada peningkatan jumlah penduduk yang masih dibawah garis kemiskinan terjadi di negaranegara tersebut (Jonaidi, 2012). Kemiskinan merupakan suatu keadaan yang dialami oleh negara yang berkembang, dan bagi negara maju yang memiliki kekayaan Sumber Daya Alam SDA maupun Sumber Daya Manusia SDM yang memadai (Astrini \& Purbadharmaja, 2013). Kemiskinan merupakan masalah utama yang dialami oleh negara berkembang(Vincent, 2009).

$$
\text { Kemiskinan diartikan dengan }
$$

ketidakmampuan seseorang untuk memproleh mata pencarian serta mendapatakan penghasilan yang layak demi menunjang kehidupan yang berkeanjutan dilihat dari rendahnya gizi, pendidikan maupun kesehatan yang rendah dan sebagainya (Paramita \& Purbadharmaja, 2015). Definisi mengenai kemiskinan semakin meluas seiring dengan faktor penyebabnya, indikataor maupun permasalahan lainnya yang terkait. Kemiskinan tidak dianggap sebagai demensi ekonomi malainkan telah meluas hingga kedimensi kesehatan, pendidikan, sosial serta politik. Kemiskinan diartikan sebagai keterbatasan yang disandang seseorang, setiap keluarga, suatu komonitas, serta sebuah negara yang menjadi penyebab terjadinya ketidaknyamanan dalam kehidupan, jika hal ini terjadi dalam penegakan hak dan keadilan, terancamnya jangka yang lebih panjang dapat mengakibantkan hilanganya generasi, serta suramnya masa depan bangsa dan negara.

Tabel 1

PDRB, Investasi Industri Kecil, Jumlah Penduduk dan Kemiskinan

Kota Lhokseumawe Tahun 2006-2016 


\begin{tabular}{|l|l|l|l|l|}
\hline Tahun & $\begin{array}{l}\text { Kemiskinan } \\
\text { (Jiwa) }\end{array}$ & $\begin{array}{l}\text { PDRB } \\
\text { (Triliun Rupiah) }\end{array}$ & $\begin{array}{l}\text { Investasi Industri Kecil } \\
\text { (Miliyar Rupiah) }\end{array}$ & $\begin{array}{l}\text { Jumlah } \\
\text { Penduduk (Jiwa) }\end{array}$ \\
\hline 2006 & 22,200 & $1,539,795.21$ & $11,552,598,000$ & 154,634 \\
\hline 2007 & 19,400 & $1,851,531.57$ & $20,177,400,000$ & 156,556 \\
\hline 2008 & 23,900 & $1,969,93.200$ & $9,585,293,000$ & 158,169 \\
\hline 2009 & 22,500 & $2,081,436.51$ & $10,095,893,000$ & 159,239 \\
\hline 2010 & 24,000 & $4,365,274.40$ & $17,806,528,000$ & 171,163 \\
\hline 2011 & 24,200 & $4,530,603.90$ & $18,046,668,000$ & 175,082 \\
\hline 2012 & 23,500 & $4,727,608.90$ & $18,211,967,000$ & 179,807 \\
\hline 2013 & 23,000 & $4,893,015.70$ & $13,721,320,000$ & 181,976 \\
\hline 2014 & 22,500 & $5,221,656.80$ & $13,721,320,000$ & 187,455 \\
\hline 2015 & 23,100 & $5,677,362.40$ & $17,296,977,000$ & 191,407 \\
\hline 2016 & 23,200 & $5,321,204.80$ & $18,148,656,000$ & 195,186 \\
\hline
\end{tabular}

Dari paparan data yang ada pada Tabel 1 diatas dapat dilihat bahwa terjadi pergerakan pada variabel kemiskinan secara fluktuatif dimana hal ini terlihat pada setiap tahunya, ditahun 2006 kemiskinan yang ada pada Kota Lhokseumawe sebesar 22,20 ribu jiwa, lalu mengalami peningkatan kembali pada tahun 2008 yaitu sebesar 23,900 ribu jiwa, serta terjadi pada tahun 2009 yang mengalami penurunan ditahun sebelumnya sebesar 22,500 ribu jiwa, namun pada tahun 2010 kembali mengalami kenaikan yang cukup tinggi pada tahun sebelumnya sebesar 24,000 ribu jiwa, dimana hal ini tidak di imbangi dengan variabel yang lainnya.

Dimana sebagai mana kita ketahui bahwa hubungan antara PDRB terhadap Kemiskinan adalahnegatif, dapat diketahui bila tingkat PDRB setiap tahunnya mengalami penigkatan maka akan memberikan dampak yang baik bagi kemiskinan akan dapat menekan angka kemiskinan yang ada. Dimana hal ini terlihat pada tabel pada tahun 2009 dimana nilai PDRB Kota Lhokseumawe mengalami penigkatan dari tahun sebelumnya yaitui 2,081,436.51 Triliun Rupiah, dan angka kemiskinan juga mengalami penurunan dari tahun sebelumnya 23,900 Ribu jiwa menjadi 22,500 Ribu jiwa.

Permasalahan terjadi pada tahun 20102011, dimana tingkat pertumbuhan ekonomi regionalnya mengalami penigkatan disetiap tahunnya namun kemiskinan pula mengalami penigkatan dari tahun sebelumnya 2010 penduduk miskin yakni 24,000 ribu jiwa menjadi 24,200 ribu jiwa pada tahun 2011.

Nilai Investasi industri kecil pada setiap tahunnya mengalami fluktuasi terlihat pada tahun 2012 mengalami penigkatan dari tahun sbelumnya sebanyak 18,211,967.000, terjadi penurunan tahun 2013 menjadi 13,721,320.000, namun pada penduduk miskin mengalami penurunan dari sebelumnya 23,5 ribu jiwa menjadi 23 ribu jiwa, dimana hal ini tidak sesuai dengan teori. Jumlah penduduk mengalami fluktuatif pada setiap tahunnya dimana hal ini terlihat pada tahun 2009 dan 2010, dimana jumlah penduduk padat ahun 2009 berjumlah sebesar 159,239, pada tahun 2010 mengalami penigkatan dari tahun sebelumnya sebesar 171,163 jiwa.

Berdasarkan paparan diatas, maka tujuan dari penelitian ini adalah untuk mengetahui besarnya pengaruh yang diberikan oleh Produk Domestik Regional Bruto, Investasi Industri kecil, danJumlahPenduduk terhadap Kemiskinan Kota Lhokseumawe.

\section{TINJAUAN PUSTAKA}

\subsection{Kemiskinan}

Kemiskinan merupakan permasalahan yang menjadi perhatian penting. Kemiskinan dapat disebabkan oleh beberapa penyebab, seperti tingkat investasi yang rendah, tingkat pengangguran yang tinggi, dan disparitas antar daerah diakibat distribusi pendapatan tidak merata sebagai akar permasalahan kemiskinan di Indonesia (Sianturi, 2011).

Garis kemiskinan yaitu ukuran yang melihat besarnya pengeluaran dalam memenuhi kebutuhan. Setiap negara mengunakan garis kemiskinan yang berbeda, sehingga tidak ada yang bersifat umum. Disebabkan oleh adanya perbedaan tempat serta standar kebutuhan hidup (Chambers, 2010) menyatakan bahwasanya kemiskinan merupakan konsep terintegrasi yang mempunyai lima dimensi, seperti:

1) Kemiskinan (proper);

2) Ketidakberdayaan (powerless);

3) state of emergency;

4) Ketergantungan (dependence);

5) Keterasingan secara geografis ataupun sosiologis.

\subsection{Pengertian PDRB}

Secara umum pertumbuhan ekonomi didefinisikan sebagai penigkatan dari suatu perekonomian dalam memproduksikan barang dan jasa. Dengan perkataan lain arah dari pertumbuhan ekonomi lebih kepada perubahan yang bersifat 
kuantitatif (quantitative change) dan biasanya dihitung dengan mengunakan data PDRB, pendapatan sertai nilai akhir pasar dari produk barang akhir dan jasa yang dihasilkan suatu pada kurun waktu tertentu selama satu tahun.

\subsection{Investasi Industri Kecil}

Investasi pada hakekatnya merupakan awal kegiatan pembangunan ekonomi. Investasi dapat dilakukan oleh swasta, pemerintah atau kerjasama antara pemerintah dan swasta. Investasi merupakan suatu cara yang dapat dilakukan oleh pemerintah untuk meningkatkan pertumbuhan ekonomi dan untuk jangka panjang dapat menaikan standar hidup masyarakatnya (Mankiw, 2003).

\subsection{Pengertian Jumlah Penduduk}

Penduduk adalah unsur penting pada kegiatan ekonomi yang menyediakan tenaga ahli, tenaga kerja serta tenaga usahawan yang dibutuhkan demi menciptakan kegiatan ekonomi, damfak dari fungsi tersebut maka penduduk merupakan unsure menciptakan dan mengembangkan tehknologi penggunaan berbagai faktor produksi. Pertumbuhan penduduk adalah keseimbangan yang dinamis yang mampu menambah dan mengurangi kekuatan pada jumlah penduduk.

\subsection{Kerangka Konseptual}

Berdasarkan teori dan penjelasan di atas, maka kerangka konseptual dalam penelitian ini adalah sebagai berikut :

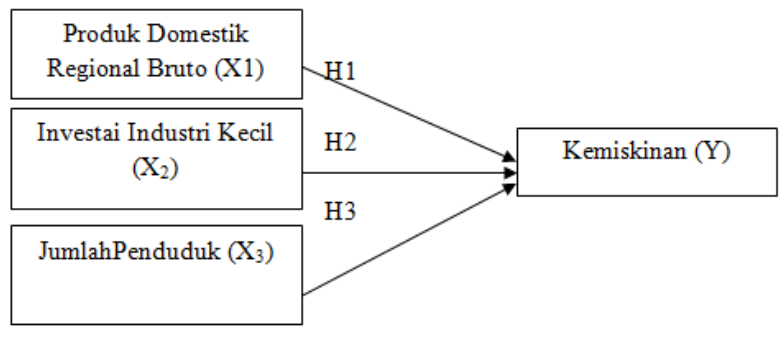

Gambar 1 Kerangka Konseptual

\subsection{Hipotesis Penelitian}

Hipotesis adalah dugaan atau pendapat sementara dan pedoman serta arah penelitian yang disususn berdasarkan pada teori yang terkait, dimana suatu hipotesis selalu dirumuskan dalam bentuk pernyataan yang menghubungkan dua variable atau lebih. Maka hipotesis dalam penelitian ini adalah:

H1 : Didunga Produk Domesti Regional Bruto (PDRB) berpengaruh terhadap Kemiskinan di Kota Lhokseumawe.

H2 : Didunga Investasi Industri Kecil berpengaruh terhadap Kemiskinan di Kota Lhokseumawe

H3 : Didunga Jumlah Penduduk berpengaruh terhadap kemiskinan di Kota Lhokseumawe

\section{METODE PENELITIAN}

\subsection{Objek dan Lokasi Penelitian}

Adapun objek yang akan digunakan oleh penulis pada penelitian ini ialah, Produk Domestik Regional Bruto (PDRB), Investasi Industri Kecil, dan Jumlah Penduduk terhadap Kemiskinan. Dan lokasi yang akan diteliti oleh penulis dengan objek yang diatas ialah daerah Kota Lhokseumawe.

\subsection{Jenis dan Sumber Data}

Jenis data yang digunakan dalam penelitian ini adalah data sekunder sebagai berikut:

1. Data PDRB Atas Dasar Harga Konstan 2010 Kota Lhokseumawe Tahun Periode 2006-2016

2. Data Investasi pada Industri Kecil baik Formal Maupun Informal di Kota Lhokseumawe tahun periode 2006-2016

3. Data JumlahPenduduk di Kota Lhokseumawetahunperiode 2006-2016

4. Data jumlah penduduk miskin di Kota Lhokseumawe tahun periode 2006-2016. Data diperoleh dari Badan Pusat Statistik Kota Lhoksemawe, Dinas Kependudukan Ketenagakerjaan dan sumber lain yang terkait dengan penelitian ini maupun internet.

\subsection{Operasionalisasi Variabel}

Adapun operasionalisasi variabel dalam penelitian ini yaitu :

1. Produk Domestik Regional Bruto (PDRB) $\left(\mathrm{X}_{1}\right)$, ) adalah peningkatan jumlah nilai tambah barang serta jasa yang dihasilkan kegiatan perekonomian daerah dari satu tahun ke tahun berikutnya. Data yang digunakan adalah PDRB atas dasar harga konstan 2010 dalam satuan rupiah (data diambil dari BPS Kota Lhokseumawe). 
2. Investasi Industri Kecil (X2) merupakan jumlah uang yang ditanamkan yang digunakan untuk memproduksi ataupun mengolah bahan mentah menjadi setengah jadi maupun bahan jadi. (Sadono, 2010) menyatakan investasi merupakan pengeluaran maupun pembelanjaan penanaman modal untuk membeli barang modal serta perlengkapan produksi guna menambah kemampuan memproduksi berupa barang serta jasa dalam perekonomian. dalam satuan rupiah (data diambil di BPS Kota Lhokseumawe).

3. JumlahPenduduk (X3) Penduduk sebagai unsure penting dalam kegiatan ekonomi Karena penduduk sebagai tenaga ahli, tenaga kerja, serta tenaga usahawan yang dibutuhkan dalam menciptaka nkegiatan ekonomi, dampak dari fungsi tersebut maka penduduk merupakan unsure menciptakan dan mengembangkan tehknologi penggunaan berbagai faktor produksi. JumlahPenduduk, dalam satuan jiwa (data diambil di BPS Kota Lhokseumawe ).

4. Kemiskinan (Y), merupakan suatu keadaan yang dialami oleh negara, daerah maupun sekelompok orang dimana mereka tidak mampu dalam memenuhi kebutuhan hidupnya, baik dibidang sandang maupun pangan, pendidikan, kesehatan dan juga sosial. Data yang digunakan adalah kemiskinan dari tahun 2006-2016, yang dinyatakan dalam satuan ribu jiwa.

\subsubsection{Metode Analisis Data}

Data yang diproleh dari sumber data, kemudian di tabulasi dan diolah dengan menggunakan rumus persentase yang berguna untuk melihat kecendrungan-kecendrungan indicator masing-masing. Selanjutnya untuk mengukur dampak dari besarnya variable-variabel, maka dianalisis menggunakan regresi linear berganda (Sugiyono, 2009). Adapun model regresinya yaitu:

\section{$\log Y=\beta 0+\beta_{1} \log X_{1}+\beta_{2} \log X_{2}+\beta_{2} \log X_{3}+e i$}

Dimana: LogY: Kemiskinan

$$
\beta 0 \quad \text { : Konstanta }
$$

$\beta_{1}, \beta_{2}, \beta_{3}$ : Koefisien regresi variabel $\log \mathrm{X}_{1} \quad$ : PDRB

$\log \mathrm{X}_{2} \quad$ : Investasi Industri Kecil

$\log X_{3}$ : JumlahPenduduk

ei : Erorr term (Variabel penganggu)

\subsubsection{Uji Asumsi Klasik}

Uji asumsi klasik dilakukan untuk mengetahui apakah model estimasi telah memenuhi kriteria ekonometrika, dalam arti tidak terjadi penyimpangan yang cukup serius dari asumsi-asumsi yang harus dipenuhi. Menurut Gujarati \&Porter (2012), pengujian asumsi klasik dalam penelitian ini tergantung pada hasil pemilihan metode estimasi. Apabila pemilihan metode estimasi yang sesuai untuk persamaan regresi adalah random effect, maka tidak perlu dilakukan uji asumsi klasik.

\section{HASIL PENELITIAN DAN PEMBAHASAN}

\subsection{Hasil Pengujian Asumsi Klasik}

Uji multikolinearitas digunakan untuk melihat hubungan antar variabel bebas. Dimana dalam penelitian ini untuk mendeteksi terjadinya multikolinearias dengan cara melihat nilai korelasinya. Menurut Gujarati 2012 multikolinearitas terjadi apabila nilai korelasi antar dua variabel bebas lebih dari 0.80 .

\section{Tabel 2}

Hasil Uji Multikolinearitas

\begin{tabular}{|l|l|l|l|}
\hline & PDRB $\left(\mathrm{X}_{1}\right)$ & Investasi $\left(\mathrm{X}_{2}\right)$ & $\begin{array}{l}\text { Jumlah } \\
\text { Penduduk }\left(\mathrm{X}_{3}\right)\end{array}$ \\
\hline $\mathrm{X}_{1}$ & 1.000000 & 0.481781 & 0.967105 \\
\hline $\mathrm{X}_{2}$ & 0.481781 & 1.000000 & 0.418205 \\
\hline $\mathrm{X}_{3}$ & 0.967105 & 0.418205 & 1.000000 \\
\hline \multicolumn{4}{|c|}{ Sumber: Hasil Penelitia 2018 (data diolah) }
\end{tabular}

Dari matriks korelasi dari masing-masing variabel bebas pada Tabel 2 diatas dapat diketahuiadanya terdeteksi Multikolinearitas anatar variabel bebas PDRB $\left(\mathrm{X}_{1}\right)$ karena nilai korelasi antar variabel bebas, $\mathrm{X}_{1}$, diatas 0.80 .

Tabel 3

Hasil Uji Autokorelasi

Breusch-Godfrey Serial Correlation LM Test:

\begin{tabular}{llll}
\hline \hline F-statistic & 0.335168 & Prob. F(2,5) & 0.7301 \\
Obs*R-squared & 1.300397 & Prob. Chi-Square(2) & 0.5219
\end{tabular}

Sumber:Hasil Penelitian 2018 (Data diolah) 
Hasil regresi koefisien PDRB $\left(\mathrm{X}_{1}\right)$

Berdasarkan Tabel 3 diatas diproleh nilai Obs*R-squared sebesar 1.300397probabilitas Chisquare 0.5219 lebih besardari nilai kritis $(\alpha=5 \%$ atau 0,05), sehingga bisa disimpulkan bahwa model tidak terdeteksi masalah autokorelasi.

Tabel 4

Hasil Uji Heteroskedastisitas

Heteroskedasticity Test: White

\begin{tabular}{llll}
\hline \hline F-statistic & 0.225457 & Prob. F(3,7) & 0.8758 \\
Obs*R-squared & 0.969220 & Prob. Chi-Square(3) & 0.8087 \\
Scaled explained SS & 0.117293 & Prob. Chi-Square(3) & 0.9897 \\
\hline
\end{tabular}

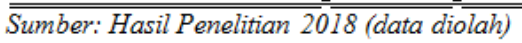

Berdasarkan Tabel 4 diatas nilai Obs*Rsquared adalah 0.969220, nilai Prob. Chi-Square 0.8087 lebihbesardari padanilai alpha 5\% (0.05) hal ini menunjukkan model tidak terdeteksi masalah Heteroskedastisitas.

\subsection{Hasil Regresi Linear Berganda}

Untuk melihat hasil analisis, penelitian ini mengunakan analisis regresi linear berganda (Multiple regression lineaer), dengan bantuan program Eviews 9, adapun hasil analisisnya dapat dilihat pada tabel berikut:

Tabel 5

Hasil Regresi Linear Berganda

\begin{tabular}{lcccc}
\hline \hline Variable & Coefficient & Std. Error & t-Statistic & Prob. \\
\hline \hline C & 17.93849 & 5.119854 & 3.503712 & 0.0099 \\
LOG(PDRB) & 0.233870 & 0.097176 & 2.406662 & 0.0470 \\
LOG(INVESTASI_INDUSTRI) & -0.154074 & 0.065188 & -2.363520 & 0.0501 \\
LOG(JUMLAH_PENDUDUK) & -0.825501 & 0.553121 & -1.492441 & 0.1792 \\
\hline \hline R-squared & 0.618120 & Durbin-Watson stat & 2.074445 \\
Adjusted R-squared & 0.454457 & & 0.067105 \\
F-statistic & 3.776783 & Prob(F-statistic) & \\
\hline \hline
\end{tabular}

Sumber: Hasil Penelitian (data diolah) 2018

Berdasarkan tabel 5 dapat dibuat persamaan regresi sebagai berikut:

$$
\log Y=\beta 0+\beta_{1} \log X_{1}+\beta_{2} \log X_{2}+\beta_{2} \log X_{3}+e i
$$

Hasilnya adalah:

\section{$\log Y=17.93849+0.233870 \log X_{1}-0.154074$ $\log X_{2}-0.825501 \log X_{3}$}

Berdasarkan hasil persamaan regresi linear berganda diatas dapat memberikan penjelasan bahwa koefisien $\beta 0$ (Konstanta) sebesar 17.93849 maka artinya apabila variabel bebas PDRB, nvestasi Industri Kecil, dan Jumlah Penduduk tidak mengalami perubahan apapun, maka kemiskinan yang terdapat pada Kota Lhokseumawe juga akan konstan sebesar 17.93849 jiwa.
$=0.233870$, menjelaskan bahwa apabila PDRB menigkat sebesar 1 miliyar rupiah, dan variable lainnya Investasi Industri Kecil, dan Jumlah Penduduk juga tidak mengalami perubahan maka akan menambah jumlah penduduk miskin sebanyak 0.233870jiwa. Variabel Investasi Industri Kecil $\left(\mathrm{X}_{2}\right)$ memproleh hasil regresi sebesar-0.154074, yang artinya jika nilaiInvestasi Industri kecil menigkat sebesar 1 juta rupiah, sedangkan variable lainnya tetap seperti PDRB dan Jumlah Penduduk, maka dapat mengurangi Jumlah Penduduk Miskin sebanyak -0.154074. Variabel Jumlah Penduduk $\left(\mathrm{X}_{3}\right)$ memiliki hasil regresi sebesar-0.825501, menunjukkan bahwa, apabila Jumlah Penduduk bertambah sebesar1 orang maka akan menurkan angka kemiskinan sebesar -0.825501 .

\subsection{Pengujian Hipotesis}

\subsubsection{Uji Secara Parsial (Uji t)}

Uji t dipakai untuk mengetahui apakah ada pengaruh variabel independen terhadap varibel dependen secara parsial. Pengujian yang digunakan dengan kriteria keputusan jika $t_{\text {hitung }}$ lebih besar darai pada t tabel maka secara parsial variabe independen berpegaruh terhadap variabel dependen, dan sebaliknya apa bila nilai t hitung lebih rendah dari t tabel, maka secara parsial variabel independen tidak berpegaruh terhadap variabel dependen.

Dari hasil pengujian regresi linear berganda pada tabel 4.8 diatas menujukkan bahwa variabel PDRB $\left(\mathrm{X}_{1}\right)$ memiliki nilai thitung sebesar 2.406662 sementara nilai pada $t$ tabel dengan $\mathrm{df}=\mathrm{n}$ k (11-4=7) pada $\alpha=5 \%$ diproleh nilai sebesar 1.89458. Maka $t_{\text {hitung }}>t_{\text {tabel, }}$ yaitu 2.406662>1.89458 degan niali signifikansi $<0,05$, maka keputusannya adalah menolak $\mathrm{Ha}$ dan menerima H1 yang dimana bahwasanya secara parsial Produk Domesti Regional Bruto (PDRB) berpengaruh terhadap kemiskinan Kota Lhokseumawe.

Variabel Investasi Industri Kecil $\left(\mathrm{X}_{2}\right)$ memilki nilai $t_{\text {hitung }}$ sebesar-2.363520, sedangkan nilai $\mathrm{t}_{\text {tabel }}$ dengan $\mathrm{df}=\mathrm{n}-\mathrm{k}(11-4=7)$ pada $\alpha=5 \%$ diproleh nilai sebesar 1.89458. Maka $t_{\text {hitung }}>\mathrm{t}_{\text {tabel }}$, yaitu $2.363520>1.89458$ dengan nilai signifikansi $<0.05$, maka keputusannya adalah menolak 
hipotesis Ha dan menerima hipotesis $\mathrm{H} 2$, yang berarti bahwasanya secara parsial variabel Investasi Industri kecil berpengaruh terhadap kemiskinan Kota Lhokseumawe.

Selanjutnya variabel Jumlah Penduduk $\left(\mathrm{X}_{3}\right)$ memiliki nilai $t_{\text {hitung }}$ sebesar-1.492441, sementara nilai $\mathrm{t}_{\text {tabel }}$ dengan $\mathrm{df}=\mathrm{nk}(11-4=7)$ pada $\alpha=5 \%$ diproleh nilai sebesar 1.89458. Maka $t_{\text {hitung }}<t_{\text {tabel }}$, yaitu $-1.492441<1.89458$ dengan nilai signifikansi $>0.05$, maka keputusannya adalah menolak H3 dan menerima Ha, yang artinya bahwa secara parsial variabel Jumlah Penduduk tidak berpengaruh terhadap kemiskinan Kota Lhokseumawe.

\subsubsection{Hasil Uji Secara Simultan (Uji F)}

Hasil pengujian pada tabel 4.8,

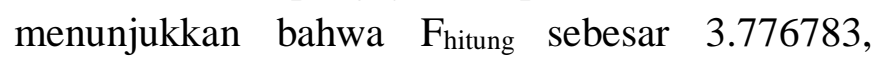
sedangkan nilai pada $F_{\text {tabel }}$ pada derajat kebebasan (dk) pembilang 4 dan (dk) penyebut 11 diproleh nilai $F_{\text {tabel }}$ sebesar 3.36 dan nilai signifikansinya $<0.05$. MakaF $F_{\text {hitung }} F_{\text {tabel }}$ keputusannya, secara bersama-sama variabel PDRB, Investasi Industri Kecil, dan Jumlah Penduduk mempengaruhi Kemiskinan di Kota Lhoksumawe.

\section{PENUTUP}

\subsection{Kesimpulan}

Berdasarkan hasil penelitian dan pembahasan, maka dapat ditarik beberapa kesimpulan sebagai berikut:

1. PDRB berpengaruh secara singnifikan dan positif terhadap Kemiskinan, namun hasil yang diproleh tidak seusai dengan teori pertumbuhan ekonomi yang ada, dimana jika PDRB menigkat maka akan menurunkan Jumlah Penduduk Miskin.

2. Investasi Industri kecil Berpengaruh secara singnifikan dan negative terhadap Kemiskinan, dimana jika Investasi Industri Kecil Menigkat maka akan mengurangi Jumlah Penduduk Miskin pada Kota Lhokseumawe.

3. Jumlah Penduduk berpengaruh tetapi tidak secara singnifikan, dan negative terhadap Kemiskinan, jika Jumlah Penduduk menigkat maka akan menurunkan kemiskinan yang ada, namun hal ini tidak sejalan terhadap teori yang ada, dimana seharusnya jika jumlah penduduk menigkat maka akan menigkatkan kemiskinan.

4. Produk Domestik Regional Bruto (PDRB), Investasi Industri Kecil dan Jumlah Punduduk secara bersama-sama atau serempak berpengaruh terhadap Kemiskinan.

\subsection{Saran}

1. Untuk penulis sebagai tambahan ilmu pengetahuan tentang bagaimana Pengaruh PDRB, Tenaga Kerja dan Investasi industri Kecil terhadap Kemiskinan Kota Lhokseuamwe pada tahun 2010-2016.

2. Bagi pemerintahan daerah Kota Lhokseumawe sendiri agar dapat menumbuh kembangkan industri-industri kecil yang terdapat pada Kota Lhokseumawe agar mampu membuka lapangan kerja yang bisa menyerap tenaga kerja, sehingga hal ini dapat menekan angka kemiskinan yang ada.

\section{KEPUSTAKAAN}

Astrini, \& Purbadharmaja. (2013). produk domestik regional bruto, pendidikan, pengangguran, kemiskinan. E-Jurnal EP Unud, 2, 384-392.

BPS. (2010). Produk Domestik Regional Bruto Menurut Lapangan Usaha.Lhokseumawe.

Chambers, R. (2010). Analisis Faktor-Faktor yang Mempengaruhi Tingkat Kemiskinan Provinsi-Provinsi di Indonesia. Skripsi Universitas Diponegoro, Semarang.

Dama, H. Y., Lapian, A. L. C., \& Sumual, J. I. (2016). Pengaruh Produk Domestik Regional Bruto ( Pdrb ) Terhadap Tingkat Kemiskinan Di Kota Manado, 16(3), 549561.

Ghozali, Imam. (2005). Aplikasi Analisis Multi Variate dengan SPSS. Badan Penerbit UNDIP, Semarang.

Gujarati, Damodar, N. (2003). Ekonometrika Dasar Terjemahan Sumarno Zain. In Erlanga, Jakarta.

Gujarati, Damodar N \& Dawn, C. Porter (2009). Dasar-Dasar Ekonometrika (Edisi 5) Terjemahan Eugenia Mardagraha. Salemba Empat, Jakarta. (2012). Dasar-Dasar Ekonometrika Buku 2 
Edisi 5 Raden Carios Manganjong (Perj).Salemba Empat: Jakarta.

Jonaidi, A. (2012). Analisis Pertumbuhan ekonomi dan Kemiskinan di Indonesia. Jurnal Kajian Ekonomi, volume 1. No.1.

Mahsunah, D. (2013). Analisis Pengaruh Jumlah Penduduk, Pendidikan dan Pengangguran terhadap Kemiskinan di Jawa Timur. Jurnal Pendidikan Ekonomi, Fakultas Ekonomi, Unesa, Kampus Ketiatang, Surabaya.

Mankiw, N. G. (2003). Teori Makro ekonomi. Erlanga, Jakarta.

Mulyadi, s. (2014). Ekonomi Sumber Daya Manusia Dalam Prefektif Pembangunan. Rajawali Pers, Jakarta.

Paramita, \& Purbadharmaja. (2015). Pengaruh Investasi dan Pengangguaran Terhadap Pertumbuhan Ekonomi Serta Kemiskinan Di Provinsi Bali. E-Jurnal EP Unud, 4(10), 1194-1218.

Sadono, S. (2010). Makroekonomi. Teori Pengantar. PT. Raja Grasindo Perseda. Jakarta.

Sharp, et al. (2000). Faktor-Faktor yang mempengaruhi Kemiskinan di Kecamatan Jelbuk kabupaten Jember. Skripsi Universitas Jember.

Sianturi, S. M. (2011). Analisis Adeterminan Jumlah Penduduk Miskin Provinsi Sumatera. Tesis Pasca Sarjana Universitas Sumatera Utara.

Sugiyono. (2009). Metode Penelitian Kuantitatif dan Kualitatif.Cv Alfabeta, Bandung.

Sukirno, S. (2000). Makro Ekonomi Modren. PT Grafindo Persada Jakarta.

Suliswanto, M. sri W. (2010). Pengaruh produk domestik regional bruto (PDB) dan indeks pembangunan manusia (IPM) terhadap angka kemiskinan di Indonesia. Jurnal Ekonomi Pembangunan, Volume 8 No 2(Desember), 357-366.

Suryono, Wiranto. Bagus. (2010). analisis pengaruh pendapatan asli daerah, tingkat investasi dan tenaga kerja terhadap PDRB Jawa Tengah. Fakultas Ekononmi, Jawa Tengah.

Vincent, B. (n.d.). The Concept Poverty towards Understanding in The Context of Developing Countries Poverty Qua Poverty. Journal of Suistainable Development.

Widarjono, A. (2009). Ekonometrika Pegantar Dan Aplikasinya. Ekonosia, Yogyakarta.
Governance. Alfabeta, Bandung.

Yacoub, Y. (2012). Pengaruh Tingkat Pengangguran terhadap Tingkat Kemiskinan Kabupaten / Kota di Provinsi Kalimantan Barat, volume 8, 176-185.

Yudha, Okta. Ryana. Pranata. (2013). Pengaruh Pertumbuhan Ekonomi, Upah Minimum, Tingkat Pengangguran Terbuka, dan Inflasi terhadap Kemiskinan di Indonesia Tahun 2009-2011. Jurnal Ekonomi Pembangunan Fakultas Ekonomi Univesrsiras Negeri Semarang. 